\title{
A KERÜLET ÉS TERÜLET FOGALMÁNAK ALAKULÁSA AZ 5-8. ÉVFOLYAMOKON ${ }^{1}$
}

\section{DEVELOPING THE CONCEPT OF PERIMETER AND AREA AMONG STUDENTS IN GRADES 5-8}

\author{
Kónya Eszter
}

\begin{abstract}
Our research examines lower secondary school students 'ideas about the concepts of area and perimeter. These concepts have taught in schools for 4-5 years however our experience shows that the knowledge of students of different ages in this content area is still superficial and often incorrect. In our study, we would like to explore the deeper causes of this phenomenon. We conducted a five-task survey at the beginning of the school year. The curriculum of mathematics has a spiral structure, so successful learning requires well-understood and easy-to-recall concepts. Therefore, we were curious about the knowledge stored in the long-term memory of the students. The same test was written in four classes, from grade 5 to grade 8 . The tasks focused on both the qualitative and quantitative characteristics of the examined concepts.
\end{abstract}

Keywords: Geometry education, area, perimeter, 97G30

\section{Bevezetés}

A kerület és terület két fontos geometriai fogalom, melyeket sok éven keresztül tanítanak az iskolában. Noha a tantervek és a tankönyvek törekszenek arra, hogy a két fogalmat ne csak a képleteken keresztül értelmezzék, hanem tevékenységeket, szemléletes fogalomképeket is rendeljenek hozzájuk, a diákok teljesítménye ezen a területen mégis alacsony. A nemzetközi szakirodalomban olvasható gondolkodási hibák és félreértések a magyar oktatási gyakorlatban is megfigyelhetők (Baturo és Nason, 1996; Vighi és Marchini, 2011; Zacharos, 2006). A területmérés megértésében elsődleges szerepe van a területmegmaradásnak, azaz annak a ténynek, hogy a terület nem változik, ha az alakzatot részekre vágjuk és a részekből új alakzatot állítunk össze. Kamii és Kysh (2006) kísérlete szerint gyakori, hogy a tanulók a részek átrendezésével kapott alakzat és az eredeti alakzat területét különbözőnek tekintik. Kospentaris, Spyrou és Lappas, (2011) arról ír, hogy a területmegmaradás felismerése még középiskolások és elsőéves egyetemi hallgatóknál is okozhat problémát, mert a geometriai érveléshez szükséges matematikai alapok hiányában a hallgatók intuitív tapasztalatokra és a vizuális észlelésre hagyatkoznak. Erős például az az intuitív elgondolás, hogy csak egybevágó alakzatok területe lehet egyenlő. A matematikai gondolkodást tanulmányozva jól ismert továbbá a „minél nagyobb A, annál nagyobb B” elv (Tsamir, 2003). Az általunk tárgyalt területen ez a „minél nagyobb egy alakzat kerülete, annál nagyobb a területe" elv kizárólagos használataként jelenik meg (Baturo és Nason, 1996, Babai, Zilber, Stavy és Tirosh, 2010)

Kutatásunk azt vizsgálja, hogy az általános iskolás tanulóknak milyen elképzelései vannak a terület és kerület fogalmáról. Ehhez egy írásbeli felmérést készítettünk. A felmérés körülményeit úgy terveztük meg, hogy a tanulóknak a hosszú távú memóriájukban tárolt tudásukra kelljen hagyatkozniuk. Az iskolában rendszerint néhány nappal az adott témakör tanítása után témazáró dolgozatot íratnak a tanárok, azonban ennek eredménye sokszor félrevezetö, hiszen sokszor tapasztaljuk, hogy néhány hónappal később a tanulók már az alapgondolatokra sem emlékeznek. A matematika tantárgy

\footnotetext{
${ }^{1}$ A tanulmány a szerző korábban megjelent írásában (Herendiné-Kónya, 2015) bemutatott felmérés tapasztalatainak kibővített és mélyebb elemzése.
} 
egymásra épülő témakörei, azaz spirális szerkezete miatt kulcsfontosságú, hogy a tanulók a korábban tanított fogalmakról stabil, könnyen elöhívható tudással rendelkezzenek.

\section{Elméleti háttér}

Baddeley, Eysenck és Anderson (2010) szerint a hosszú távú memória két fő részből áll. A deklaratív memória a fogalmak, összefüggések, elvek, problémamegoldó készségek tárolásának helye, míg a procedurális memóriában a korábban elsajátított eljárások lépései tárolódnak. A deklaratív memórián belül megkülönböztetjük az ismeretek fogalmi szintű tárolását (szemantikus memória) és az átélt eseményeket tároló epizodikus memóriát (1. ábra). A kutatások kimutatták, hogy ha ugyanaz a megtanult elem több helyen tárolódik az emlékezetben, akkor könnyebb elöhívni. Ez azt is jelenti, hogy bármit tanítunk, célszerü azt személyes tapasztalatokkal is megerösíteni. Fontos az is, hogy a megszerzett fogalmi tudást a szemantikus memóriában sémákba szervezve tároljuk, mert így, a tárolt kapcsolatokon keresztül könnyebb mind megőrizni, mind előhívni (Skemp, 1975).

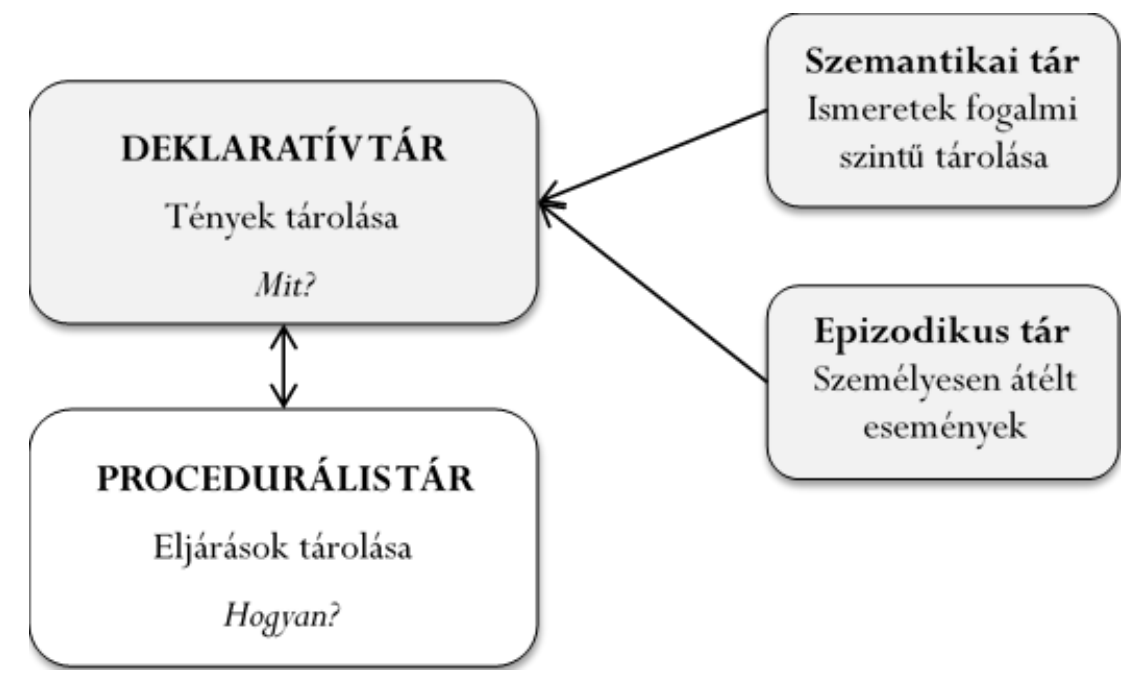

1. ábra. Többszörös emlékezeti rendszer

A kerület és terület egyidejüleg geometriai fogalmak és mérhető mennyiségek. A kvalitatív megközelítés a síkidomok egy-egy jellemzőjeként értelmezi a kerületet és területet, jól meghatározható fogalmi képeket rendelve hozzájuk. A kerületet a síkidom körbekerítésével, míg a területet a lefedésével azonosítja. A kvantitatív megközelítés ugyanakkor a hosszúságok mérése mellett a kiszámítási módokra koncentrál. A tapasztalatok azt mutatják, hogy a tanulói hibák jó része a két megközelítés közötti átjárás hiányából, valamint a kiszámítási képletek túl korai bevezetéséből adódik. Felmérésünk feladatai mindkét megközelítésre építenek.

A matematikai fogalmak megértését vizsgálva, Usiskin (2015) öt szintet különböztetett meg (2. ábra). Az alábbiakban a kerület és területfogalmakhoz kapcsolódva mutatjuk be, hogy mit jelent az, ha valaki az adott szinten megérti az adott fogalmakat.

- Algoritmuskövető megértés: tudjuk, hogy hogyan kapható meg a válasz egy kérdésre. Egy adott alakzat területének/kerületének meghatározásához ki tudjuk választani a megfelelő kiszámítási módszert.

- Értelmező megértés: tudjuk, hogy miért helyes az a módszer, ami a válaszhoz vezet. Ismerjük az alapképletek levezetéseit és a kapcsolatot ugyanazon alakzat területe és kerülete között.

- Alkalmazói megértés: tudjuk a fogalmat modellként használni, azaz tudjuk, hogy mikor kell alkalmazni. Felismerjük a terület/kerületmérést a mindennapi élethez kötődő feladatok vagy komplex problémák megoldásában. 
- Reprezentáló megértés: tudjuk reprezentálni a fogalmat egy vagy többféle módon (konkrét tárggyal, képpel vagy szófordulattal). Meg tudjuk határozni a területet egybevágó mintákkal történő lefedéssel, átdarabolással, a kerületet a határoló vonal hosszának mérésével.

- Történelmi-kulturális megértés: tudunk a fogalom matematikatörténeti hátteréről és arról, hogy hogyan jelenik meg különbözö kultúrákban. Ismerjük például a területfogalom jelentőségét az ókori matematikában, tudjuk, hogy a fogalmat a szorzás reprezentálására is használták.

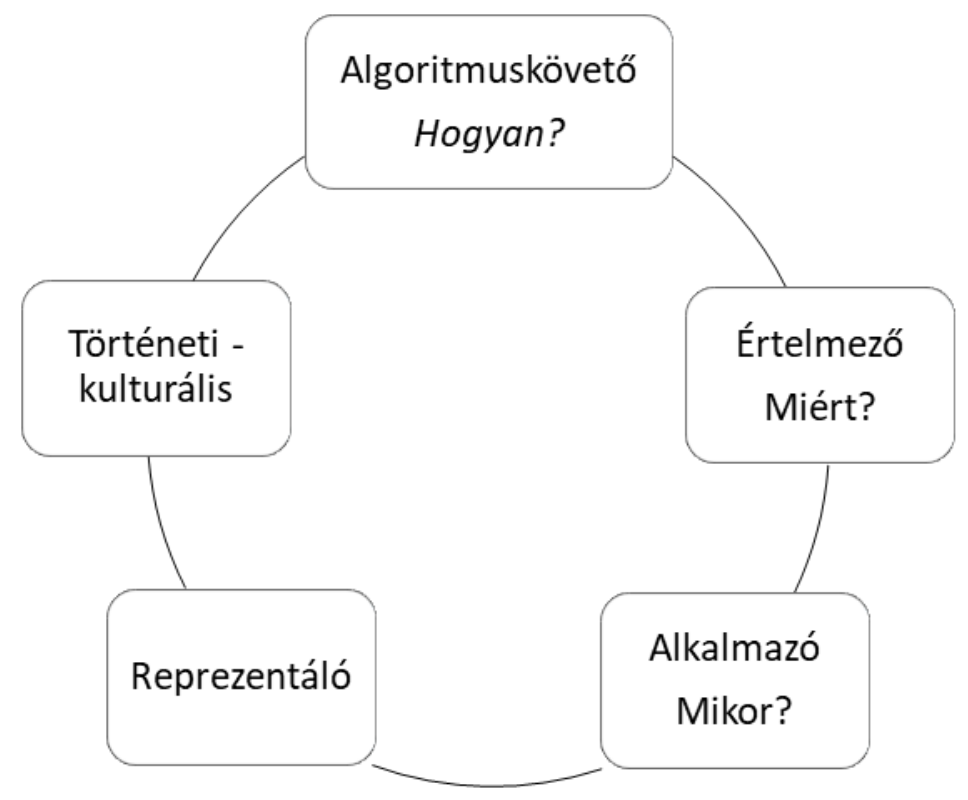

2. ábra: A matematikai megértés szintjei

Usiskin tanulmányában hangsúlyozta, hogy a szintek nem különíthetők el élesen egymástól, de mégis, sokszor tapasztalható, hogy bármelyikben elörehaladást lehet elérni külön is. Éppen ezért nincs értelme a szintek között nehézségi sorrend megállapításának, erre csak az azonos szinthez tartozó feladatok között kerülhet sor. A megértés természetesen annál mélyebb, minél több szinten vagyunk képesek jól dolgozni, így a tanításnak koncentrálnia kell arra, hogy egy-egy fogalmat minél több szinten megismertessen és megértessen a tanulókkal. Jelen kutatásunk az algoritmuskövető, az alkalmazó és a reprezentáló szintekre fókuszál.

\section{Kutatási kérdés, hipotézis}

1. Mit jelent a kerület és terület a tanulók számára a különböző évfolyamokon?

2. Milyen tipikus stratégiákat használnak, és milyen gondolkodási hibákat vétenek miközben területre és kerületre vonatkozó feladatokat oldanak meg?

Feltételezésünk szerint

1. az idősebb tanulók jobban teljesítenek mindhárom vizsgált megértési dimenzió vonatkozásában.

2. a leggyakoribb hibák a képlet és a fogalom helytelen összekapcsolásából erednek.

\section{A kutatás módszertana}

A tanév első hetében ugyanazon iskola négy különböző évfolyamának azonos program szerint haladó osztályaival egy 30 perces írásbeli felmérést végeztünk.

A kiválasztott általános iskola kiemelt helyzetü, évről évre kiemelkedően szerepel az országos kompetenciaméréseken. Minden évfolyamról az „a” osztályok vettek részt a felmérésben. Az 5/a-ból 
25, a 6/a-ból 29, a 7/a-ból 19 és a 8/a-ból 21 fő. Ezek az osztályok nyelvi tagozatosak, a matematikát csak a minimálisan elöírt heti 3 vagy 3,5 órában tanulják. A tanulók jó általános képességüek, de matematikából nem mutatnak kimagasló érdeklödést vagy tehetséget.

Az 1-3. feladat azonos volt az 5-8. évfolyamon, míg a 7-8. évfolyam kapott két további feladatot, mivel feltételeztük, hogy ök az 1-3. feladatot kevesebb idő alatt oldják meg. A tanulók ismerték a feladattípusokat, iskolai képzésük során kellett már találkozniuk hasonlókkal. Az egyes feladatokhoz valódi méretủ ábrákat készítettünk, így a megadott adatok összhangban voltak a rajzzal.

A felmérésre a 2014/15-ös tanév első hetében került sor, azért, hogy a tanulók csak az előző tanévben szerzett ismereteikre támaszkodhassanak. Feltételeztük, hogy a nyári szünet 3 hónapja alatt nem foglalkoztak ilyen jellegü matematikafeladatokkal.

\section{A teszt felépítése}

1. feladat. Határozzuk meg a téglalapok kerületét és területét! (3. ábra)
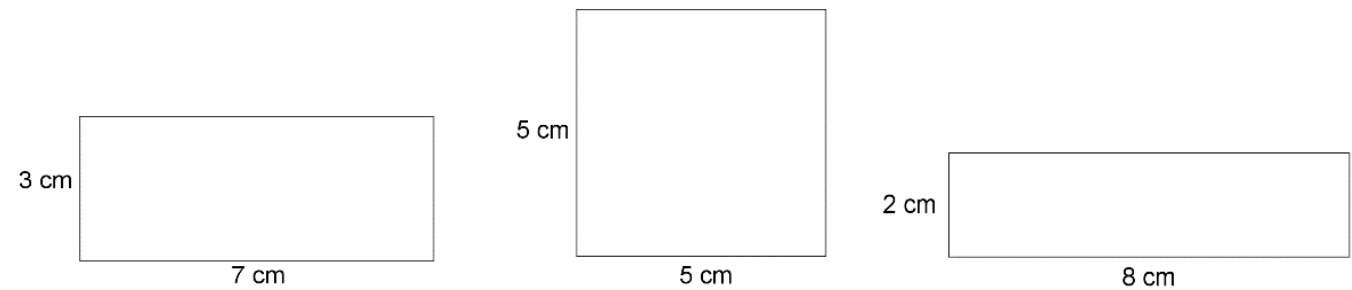

3. ábra: Azonos kerületü téglalapok

A feladat a vizsgált fogalmak kvantitatív megközelítését kéri, az algoritmuskövető megértési szintet vizsgálja. Arra voltunk kíváncsiak, hogy a tanulók helyesen használják-e a kiszámítási képletet. Ez egy jól ismert rutinfeladat, a téglalapok valós méretűek voltak, és a papírlapon a megszokott helyzetben szerepeltek.

2. feladat. Határozzuk meg az alakzat kerületét és területét! (4. ábra)

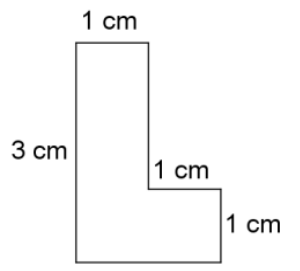

4. ábra: Lépcsős alakzat kerülete és területe

Ennél a feladatnál mind a kvantitatív, mind a kvalitatív megközelítésre szükség volt. Az algoritmuskövető megértés mellett az alkalmazó megértést is igényelte, hiszen például a területet két téglalap területére kellett visszavezetni. A helyes megoldáshoz a tanulóknak rendelkezniük kellett stabil fogalomképzettel, azaz a kerületet a határoló vonal hosszaként, a területet additív mennyiségként kellett értelmezniük. A rajzon csak a minimálisan szükséges hosszúságokat adtuk meg.

3. feladat. Mennyi a háromszög területe, ha két szomszédos rácspont távolsága $1 \mathrm{~cm}$ ? (5. ábra) Rajzolj a rácsra még két másik alakzatot, amelynek a területe ugyanakkora, mint a háromszögé!

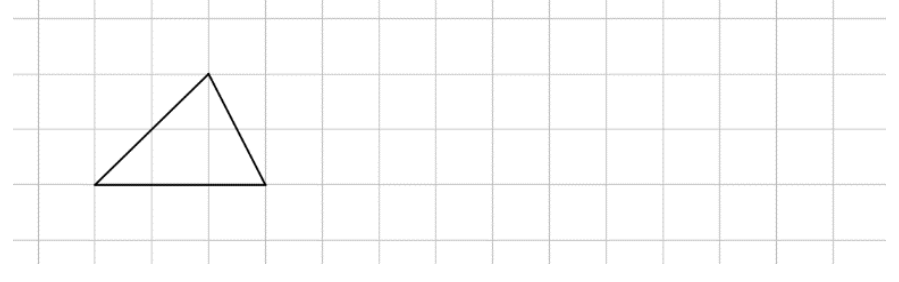


5. ábra: Háromszög területének meghatározása

A feladatszituáció elsősorban a kvalitatív megközelítést támogatja és a reprezentáló megértést igényli. A fogalom ismeretében a háromszög területe többféleképpen is meghatározható: a lefedö egységnégyzetek megszámolásával, a háromszög alkalmas átdarabolásával vagy a területképlet alkalmazásával. Az adott területủ háromszögek helyes megrajzolása a fogalom reprezentáló szintü megértésére utal.

4. feladat (7-8. o.). Mekkora a háromszög területe? (6. ábra)

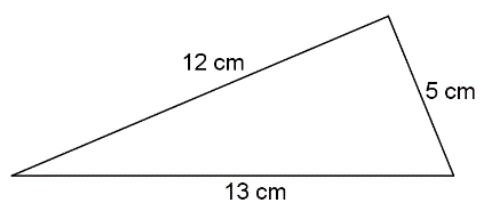

6. ábra: Háromszög területének kiszámítása

Ez a feladat az alkalmazó és az algoritmuskövető megértési szintet érinti, annak mennyiségi aspektusára fókuszál. Azzal, hogy a három oldal hosszát adtuk meg (nem pedig egy oldal és a hozzá tartozó magasság hosszát), vizsgálni tudtuk, hogy a magasság szerepe a területszámításban mennyire mély ismeret a 7-8. osztályos tanulók esetén. Arra is kíváncsiak voltunk, hogy van-e olyan tanuló, aki felismeri, és fel tudja használni, hogy a háromszög derékszögü.

5. feladat (7-8. o.). Mekkora a paralelogrammák területe? A szükséges adatokat vonalzóval mérd meg! (7. ábra)
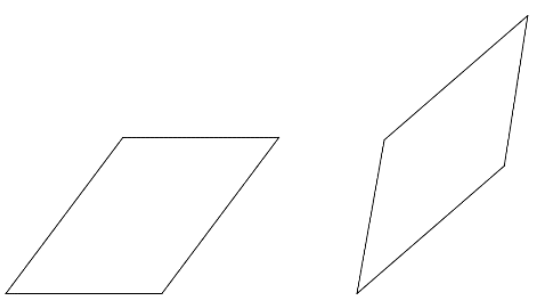

7. ábra: Azonos kerületü paralelogrammák

A két paralelogramma oldalainak hossza és így a kerülete is megegyezik, a szögeiknek nagysága különbözö. Az első hagyományos helyzetü, a második nem. A feladat megoldásához a fogalom kvantitatív megközelítése mellett szükség van a kvalitatívra is, hiszen szemmel jól látható, hogy a második paralelogramma területe kisebb. Az alkalmazó és a reprezentáló szintủ megértéssel a feladat megoldható.

\section{Tapasztalatok}

\subsection{A kerületfogalom megértésének szintjeiről}

Az összes tanuló 94\%-a helyesen válaszolt az 1. feladat kérdéseire, ami azt jelzi, hogy a legegyszerübb rutinfeladat megoldásának módját a legtöbben elsajátították már 4. osztályos korukban.

A 2. feladat esetében már jóval árnyaltabb a kép. A helyes válaszok aránya kevesebb, mint 40\%. A 8. ábrát elemezve látható, hogy a kerületfogalom (algoritmuskövető és alkalmazó) megértési szintje az évek során nem nö. Igaz, hogy a hibás téglalap-analógia 8. osztályban eltünt, viszont megjelent egy újabb hiba, a kerületek összeadása. 


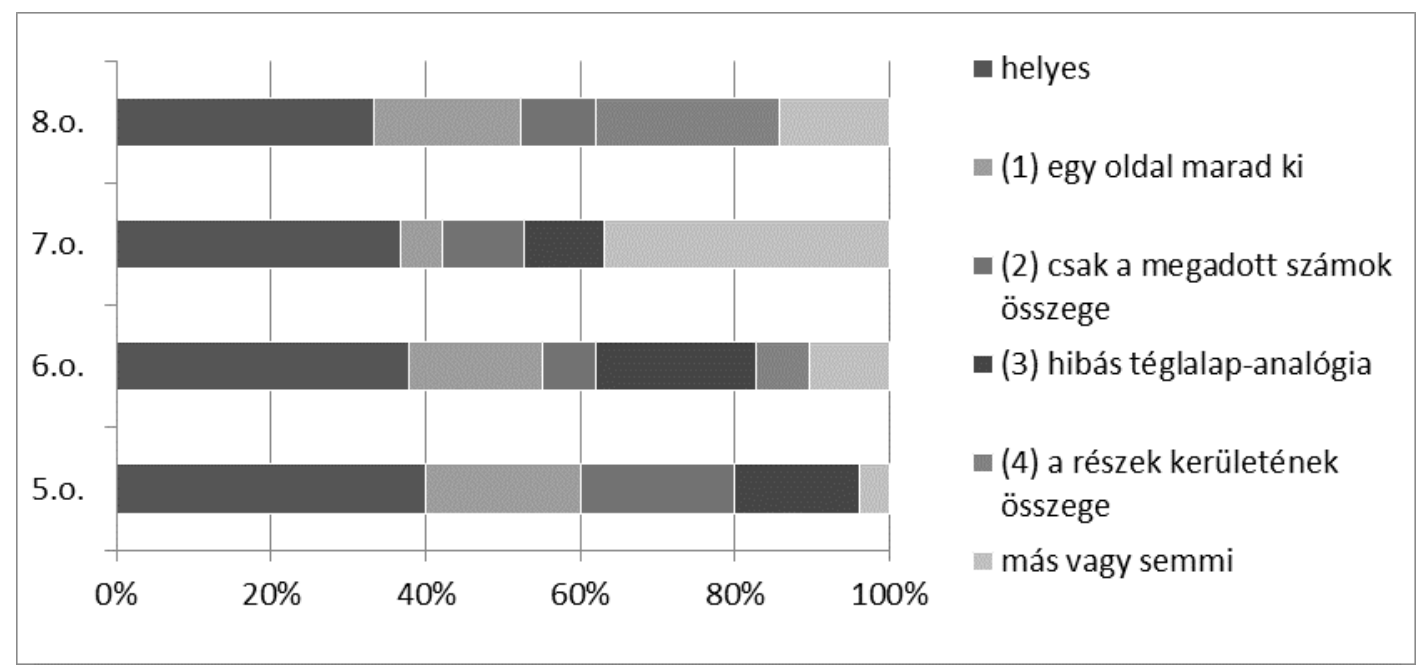

8. ábra: A kerületfogalom megértése a 2. feladat alapján

Négyféle típushibát észleltünk:

(1) A tanulók gyakran kihagynak egy vagy két oldalt (rendszerint a függőleges $2 \mathrm{~cm}$-est) az összeadásból.

(2) Csak az ábrába beírt számokat adják össze, ami a kerületfogalom kvalitatív megértésének hiányára utal.

(3) Viszonylag sok tanuló alkalmazott olyan hibás képletet, mely formailag hasonlít a téglalap kerületképletére. Például $(3 \mathrm{~cm}+1 \mathrm{~cm}+1 \mathrm{~cm}+1 \mathrm{~cm}) \times 2$. Ezt a hibatípust nevezzük ,hibás téglalap-analógiának" (9. ábra).

(4) A kerület „additivitása” is megjelent a következő módon: néhány tanuló felosztotta az alakzatot két téglalapra, azok kerületét meghatározta és összeadta. Vighi és Marchini (2011) ezt a jelenséget „terület-kerület konfliktus”-nak nevezi, azaz a területszámítási eljárás alkalmazásáról beszél a kerületszámításban. Az egyetlen különbség nálunk az, hogy ez nem a 4., hanem a 8.- évfolyamon történt.

Minden évfolyamon találtunk olyan tanulót, aki következetesen keverte a kerület és terület fogalmakat, vagy legalábbis az elnevezéseket. (Évfolyamonként rendre 4, 1, 2 és 1tanuló).

2. Határozd meg az alakzat területét és kerületét!

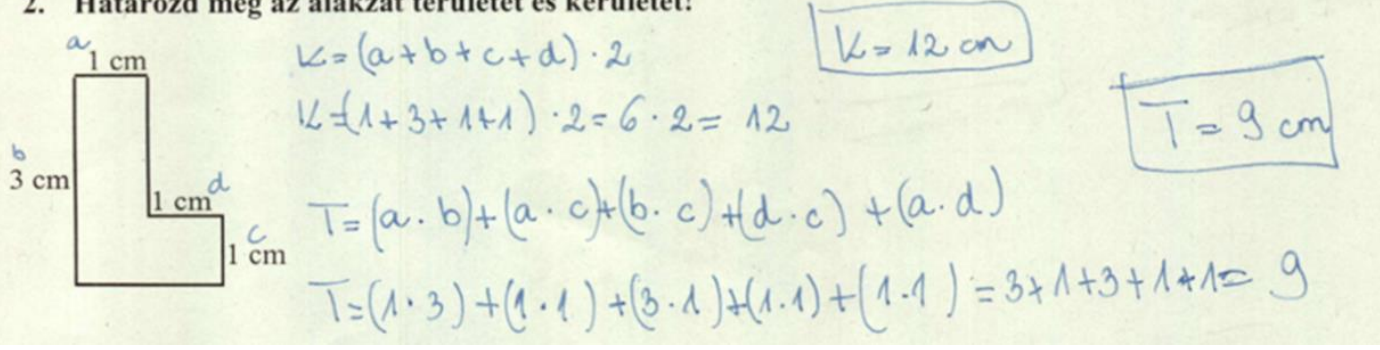

9. ábra: Hibás téglalap-analógia (Dorina, 7. o.)

\subsection{A területfogalom megértésének szintjeiről a 3. feladat alapján}

Helyes területfogalma annak a tanulónak van, aki jól megadja a háromszög területét $\left(3 \mathrm{~cm}^{2}\right)$ és képes ilyen területü, nem feltétlenül egybevágó) alakzatokat rajzolni a négyzethálóra. A kvalitatív és kvantitatív megközelítés egységét az jelenti, hogy a tanuló képes kapcsolatot teremteni a kép és a számítás között. 


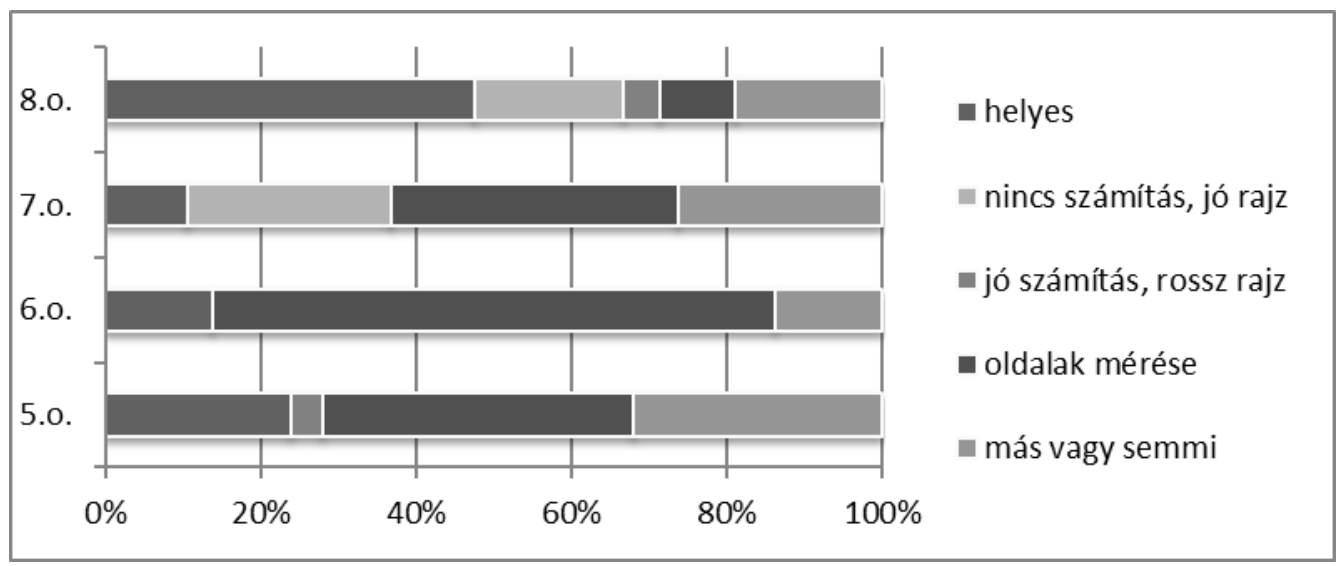

10. ábra: A területfogalom megértése a 3. feladat alapján

A „,nincs számítás, jó rajz” kategóriába azok a tanulók kerültek, akik általában két, az eredetivel egybevágó háromszöget rajzoltak. A leggyakoribb hiba az oldalak hosszának összeszorzása volt. A 11. ábrán látható megoldás az oldalak (helytelen) mérésével, majd összeszorzásával adja meg a háromszög területét. Részben helyes fogalomképre utal, hiszen a 4 területegységet négyzetekből álló alakzatra helyesen értelmezi a tanuló.

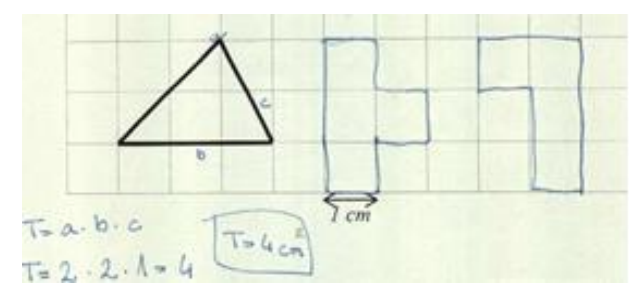

11. ábra: A 3. feladat megoldása (Dorina, 7. o.)

A helyes válaszok aránya alacsonyabb, mint a kerület esetén volt, és azt is megállapíthatjuk, hogy a 8.osok teljesítménye volt a legjobb, jobb, mint a kerület-feladatban. A 6-7. osztályokban a helyes megoldások aránya alacsonyabb nem csak a 8. de még az 5. osztályosokénál is. Ez arra enged következtetni, hogy ők nem emlékeztek arra, hogy a négyzetráccsal is meghatározható a terület, így csak valamiféle képlettel (oldalak szorzata) próbálkoztak.

\subsection{A területfogalom megértésének szintjeiről a 2. feladat alapján}

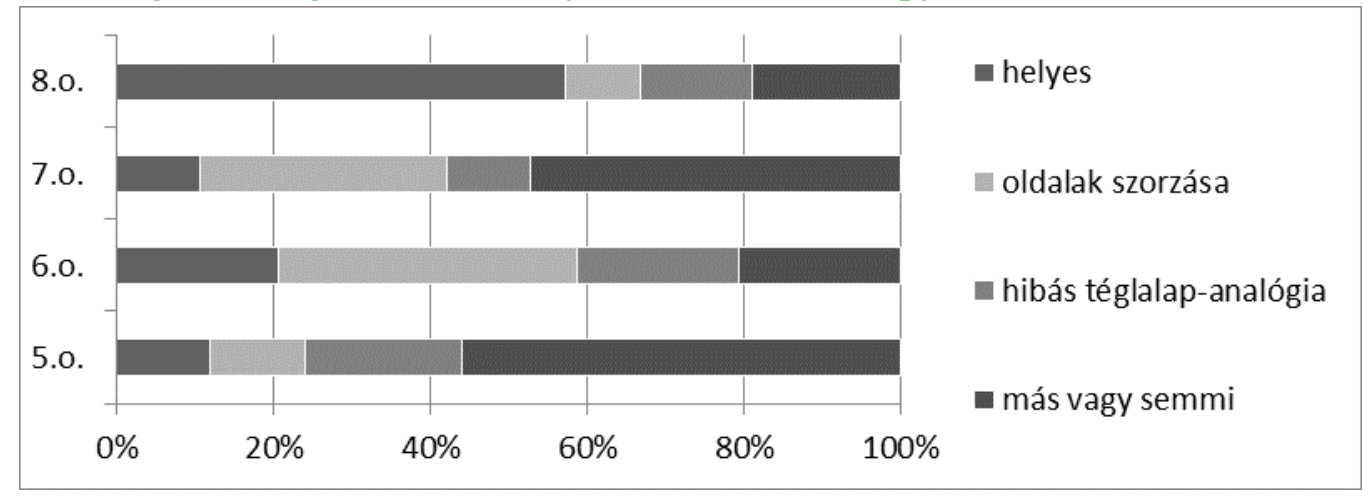

12. ábra: A területfogalom megértése a 2. feladat alapján

A helyes válaszok aránya csak a 8. osztályban éri el az 50\%-ot, noha a lépcsős alakzat téglalapokra bontásának technikája már 4 . évfolyamon megjelenik a tananyagban. Tipikus hibás stratégia itt is 
néhány vagy az összes oldal összeszorzása, valamint a hibás téglalap-analógia, például egy, a téglatest felszínének kiszámítási képletére emlékeztető eljárás alkalmazása (9. ábra).

\subsection{A területfogalom megértésének szintjeiről az 1-3. feladat alapján}

A 13. ábra az 1-3. feladatban a terület meghatározására adott helyes válaszokat mutatja. Ez alapján megállapíthatjuk, hogy az alkalmazói megértés szintje mindegyik osztályban alacsonyabb az algoritmuskövető szintnél, továbbá, hogy a reprezentáló megértés mindenütt hasonlóan alacsony szintű, mint az alkalmazói. Az 5.-esek reprezentáló megértési szintje ugyanakkor magasabb, mint a 67.-eseké. Csak 8. osztályban látszik, hogy a fogalom megértése komplexebbé vált, azaz itt közel 50\%os mindhárom szinten a megértés.

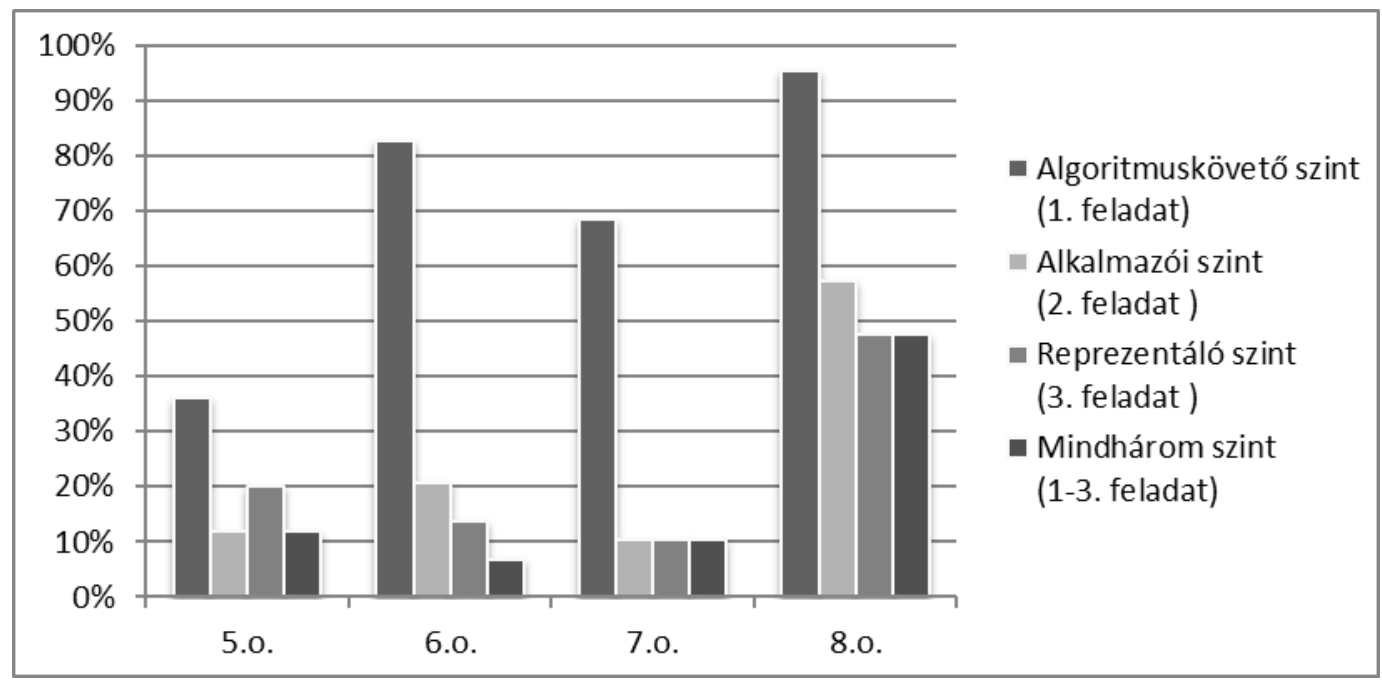

13. ábra: A terület helyes meghatározása

A 4. és 5. feladatok elemzése megerősíti az eddigi tapasztalatokat. A háromszög és a paralelogrammák területének meghatározásánál tipikus hiba az oldalak hosszának összeszorzása. A háromszög esetén ez három oldal szorzatát jelenti, míg a paralelogrammát sokszor úgy kezelték, mintha téglalap lenne, azaz a két különböző hosszúságú oldal szorzatával számoltak. Egyértelmüen kiderült a vizuális kontroll hiánya is, hiszen a két paralelogramma területe láthatóan eltér egymástól, míg a két oldal hosszának szorzata azonos lett. Az eltérö helyzetü paralelogrammáknál a 8.-osok közül 6 fő alkalmazott eltérö kiszámítási módszert. A második esetben ez az átlók hosszára vonatkozott, a deltoid területképletéhez analóg módon. Nem meglepő, hogy az alakzat láttán többen a deltoidra gondoltak, mert ez az a négyszög, amit jellemzően úgy rajzolunk fel, hogy az oldalai között nincs olyan, ami a lap szélével párhuzamos lenne. A derékszögü háromszöget mindkét osztályban 1-1 fö ismerte fel.

\section{6. Összegzés}

Általánosságban elmondható, hogy a fogalmak komplex megértésének hiánya jellemzi a felmérésben szereplö, 5-8. osztályt kezdő tanulókat. A kerület és terület fogalma elsődlegesen a téglalap kiszámítási képletével azonosul, így tipikus hibaként jelenik meg a fogalom összekapcsolása az oldalalak szorzatával. Újabb kiszámítási képlet bevezetése pedig könnyen újabb megértésbeli zavarokhoz vezet.

Az idősebb tanulók teljesítménye sok esetben nem jobb, mint a fiatalabbaké. A területröl alkotott fogalomképzet nem feltétlenül fejlődik, a tanulók elfelejtik, amit korábban tudtak. Ráadásul az újabban szerzett tudás is vezethet újabb típusú hibára.

Az alakzat elhelyezkedésének a papírlapon a megoldást befolyásoló szerepe van. Egyértelmüen kiderült, hogy hiányzik a számítási eredmény ellenőrzése, esetünkben a vizuális kontroll.

A fogalmi zavar lehetséges okai között a következőket említjük meg: 
- Hosszúságot mérünk, és abból számítunk területet. A terület így nem mérendő mennyiségként, hanem valamely képlet szerinti számolási eredményként rögzül a tanulók memóriájában (Herendiné-Kónya, 2013).

- A „minél nagyobb a kerület, annál nagyobb a terület” intuitív szabály alkalmazása, hibás vizuális becslés.

- Képlethasználatra törekvés, a kvantitatív megközelítés dominanciája.

- Emlékezeti torzítás - hamis memória: „Amikor információink elégtelenek vagy bizonytalanok, a meglévő támpontok alapján beinduló sémáink segítenek a helyzet, esemény vagy tárgy értelmezésében.” (N. Kollár és Szabó, 2004)

- A terület és kerület szavak hangzása a magyarban hasonló, könnyen összekeverhető.

- Sokszor a köznyelvi szövegek téglalapra gondolnak, de nem mondják ki. Ezzel olyasmit sugallanak, mintha csak a téglalapnak lenne területe. Ezt a meglátásunkat az alábbi három idézettel támasztjuk alá:

„... a Fegyvernek-Örményes és Kisújszállás közötti szakaszán a vasúti pálya felújításakor kerültek elő II. világháborús lőszerek. 200 méteres területet kellett teljesen átvizsgálni és löszermentesíteni, egy hétig vonatpótló autóbuszok jártak.” (2013. július 20. MTI/Index)

„Lőcse város népei, akik jelen vagytok, íme, figyelmeztetlek benneteket, nézzétek meg és mérjétek ki lépéssel ezt a területet, melyet a bíró uram vére kerít körül,..." (Mikszáth: A fekete város)

„Amennyi földet körüljársz, mind a tiéd.” (Tolsztoj: Mennyi föld kell az embernek?)

A hétköznapi nyelvhasználatból eredő félreértések, félreértelmezések befolyásolhatják a matematikai fogalmak megértését és megjegyzését. Ezért a matematikatanítás során ki kell térnünk ezekre a jelenségekre. A felmérés tapasztalataiból levonható az a következtetés is, hogy a tanulók könnyen elfelejtik a fogalmakat és eljárásokat, ha nincs lehetőségük kellően elmélyíteni és folyamatosan gyakorolni azokat. Nem szabad, hogy a tanárt megtévesszék az témakörök lezárása után közvetlenül íratott dolgozatok jó eredményei.

\section{Irodalomjegyzék}

Babai, R., Zilber, H., Stavy, R. \&Tirosh, D. (2010): The effect of intervention on accuracy of students' responses and reaction times to geometry problems. International Journal of Mathematical Education, $8,185-201$.

Baddeley, A., Eysenck, M.W., \&Anderson, M.C. (2010): Emlékezet. Akadémiai Kiadó, Budapest.

Baturo, A., \&Nason, R. (1996): Student teachers' subject matter knowledge within the domain of area measurement. Educational Studies in Mathematics, 31, 235-268.

Herendiné-Kónya, E. (2013): A méréstanítás általános szempontjai. In E. Herendiné-Kónya (Ed.): A matematika tanítása alsó tagozaton. Nemzedékek Tudása Kiadó, Budapest, 240-248.

Herendiné-Kónya, E. (2015): The level of understanding geometric measurement, In K Krainer \& N Vondrová (Eds.): Proceedings of the ninth congress of the European Society for Research in Mathematics Education, Charles University in Prague, and ERME, Prague, 536-542.

Kamii, C. \&Kysh, J. (2006): The difficulty of „length $\times$ with”: Is a square the unit of measurement? Journal of Mathematical Behavior, 25, 105-115.ing students' strategies

N. Kollár, K. és Szabó, É. (2004): Pszichológia pedagógusoknak, Osiris Kiadó, Budapest.

Kospentaris, G., Spyrou, P. \&Lappas, D. (2011): Exploring students' strategies in area consevation geometrical taks. Educational Studies in Mathematics, 77(1), 105-127.

Skemp, R.R (1975): A matematikatanulás pszichológiája. Gondolat Kiadó, Budapest. 
Tsamir, P. (2003): Using the intuitive rule more A - more B for predicting and analyzing students' responses in geometry. International Journal of Mathematical Education in Science and Technology, 34(5), 639-650.

Usiskin, Z. (2015): What does it mean to understand some mathematics? In S. J. Cho (Ed.): Selected Regular Lectures from the 12th International Congress on Mathematical Education. Springer, Seoul, 821-841.

Vighi, P. és Marchini, C., (2011): A gap between learning and teaching geometry. Paper presented at the CERME7 Conference, Rzeszow, Poland.

Zacharos, K. (2006): Prevailing educational practices for area measurement and students' failure in measuring areas. Journal of Mathematical Behavior, 25, 224-239.

\section{Szerzó}

Kónya Eszter, Unversity of Debrecen (Hungary). eszter.konya@ science.unideb.hu 